\title{
PROPOSAL
}

\section{BENTUK TINDAK TUTUR DALAM FILM PENDEK SETENGAH HARI KURANG SEDIKIT}

Tugas Mata Kuliah Metode Penelitian Pembelajaran Bahasa Indonesia Yang Diampu Oleh Prof. Dr. Syahrul R, M.Pd.

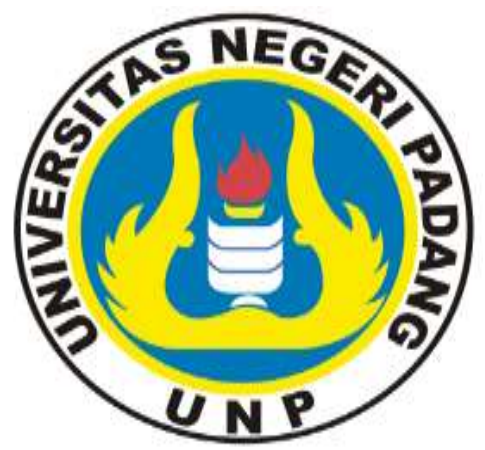

Pebi Kusuma Dewi

19016039

PROGRAM STUDI PENDIDIKAN BAHASA INDONESIA

JURUSAN BAHASA DAN SASTRA INDONESIA DAN DAERAH

FAKULTAS BAHASA DAN SENI

UNIVERSITAS NEGERI PADANG 


\section{KATA PENGANTAR}

Puji syukur kepada Allah SWT yang telah melimpahkan rahmat, karunia, dan hidayahNya kepada kita, sehingga penulis dapat menyelesaikan proposal berjudul "Bentuk Tindak Tutur dalam Film Pendek Setengah Hari Kurang Sedikit” dengan sebaik-baiknya. Penulis benar-benar mendapatkan banyak pengalaman dan pengetahuan dalam proses pembuatan proposal ini.

Shalawat beserta salam kita sampaikan kepada nabi Muhammad SAW, karena beliau patut kita jadikan sebagai contoh teladan dalam melaksanakan berbagai aktivitas demi kesejahteraan hidup kita baik di dunia maupun di akhirat nantinya.

Sejak awal penyusunan proposal ini, memang banyak sekali kesulitan yang penulis alami. Namun, berkat pertolongan dari Allah SWT dan juga diiringi dengan usaha yang maksimal, sehingga penulis dapat menyelesaikan proposal ini sesuai dengan waktu yang telah ditentukan. Ucapan terima kasih juga penulis ucapkan kepada Prof. Dr. Syahrul R, M.Pd. selaku dosen pembimbing saya yang tidak pernah lelah memberikan petunjuk, kritikan dan saran pada perbaikan proposal ini agar lebih baik lagi. Akhirnya doa dan harapan penulis sampaikan kepada semua pihak yang ikut serta dalam penyusunan proposal ini, semoga proposal ini dapat bermanfaat dan bernilai ibadah disisi Allah SWT.

Padang, 16 Desember 2021

Pebi Kusuma Dewi 


\section{DAFTAR ISI}

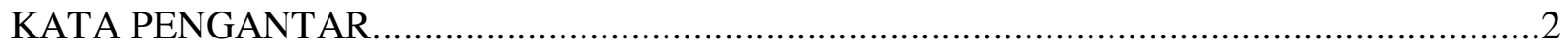

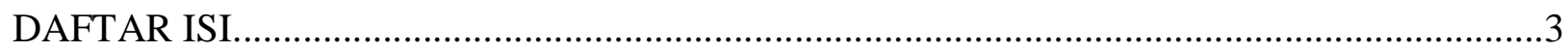

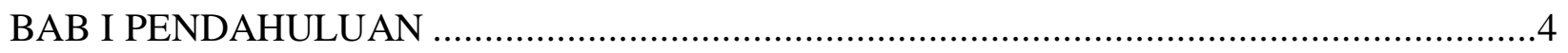

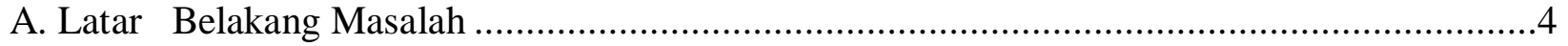

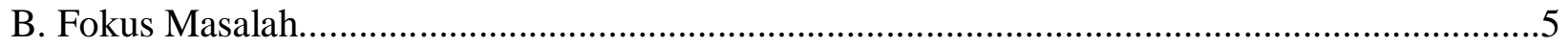

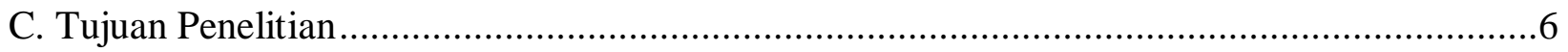

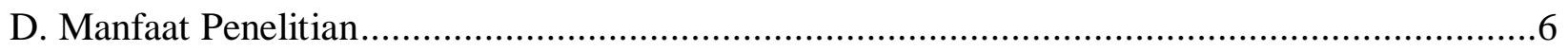

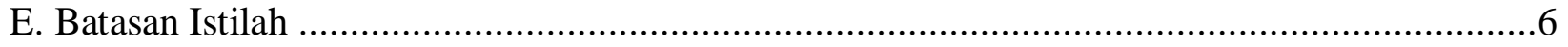

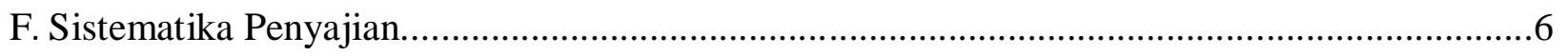

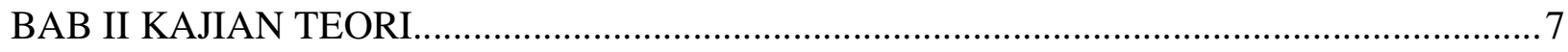

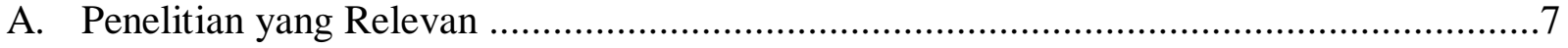

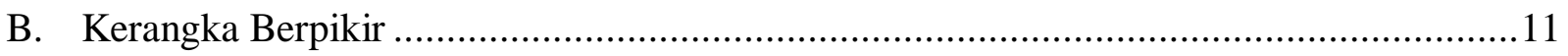

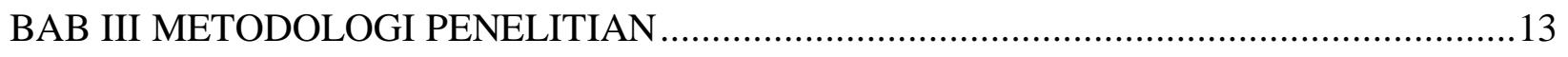

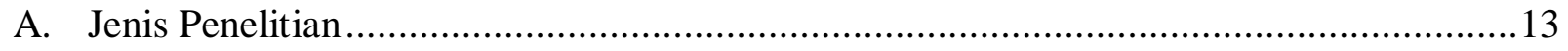

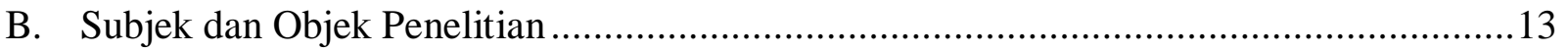

C. Sumber Data Penelitian .................................................................................. 13

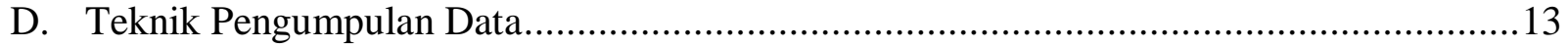

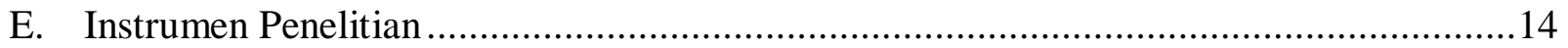

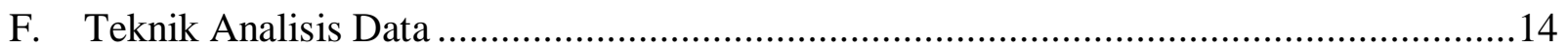




\section{BAB I}

\section{PENDAHULUAN}

\section{A. Latar Belakang Masalah}

Menurut Miranda (2018) bahwa setiap harinya manusia membicarakan hal yang berbeda sesuai dengan situasi, latar, orang-orang yang terlibat dalam pembicaraan tersebut (partisipan), dan topik pembicaraan itu sendiri. Hal tersebut terjadi karena adanya komunikasi antar individu. Sejalan dengan itu, menurut Frandika dan Idawati (2020: 62) komunikasi memiliki arti sebagai ungkapan yang akan disampaikan oleh si penutur terhadap lawan tuturnya. Namun, terkadang maksud yang ingin disampaikan oleh si penutur tidak dapat dipahami oleh si pendengar. Oleh sebab itu, strategi sangat perlu dalam suatu tindak tutur, karena dalam suatu ujaran yang penyampaiannya baik akan menggunakan strategi bertutur yang tepat, sehingga maksud yang ingin disampaikan kepada mitra tutur tersampaikan dengan baik (Rosnilawati, 2013: 462).

Tindak tutur juga sangat berkaitan dengan film. Menurut Ismiati (2020: 258) menyatakan bahwa film sebagai media penyampaian pesan yang memberikan hiburan bagi para penonton. Hal inilah yang menjadikan film sebagai media penyampaian pesan yang layak untuk dikaji pada kajian tindak tutur. Ketika memahami sebuah film, setiap penonton film memiliki persepsi berbeda-beda dalam memahami makna didalam film tersebut disesuaikan dengan konteks yang ada (Ratna dan Kustinah, 2019:180). Menurut Maulidah (2020) sebuah film tidak terlepas dari dialog atau percakapan yang terjadi antara dua tokoh atau bahkan lebih. Dialog atau percapakan ini erat kaitannya dengan tindak tutur. Tuturan dalam film tersebut diduga memiliki variasi bentuk dan jenis tindak tutur. Ketika mengungkapkan suatu kalimat, seseorang tidak hanya mengatakan sesuatu dengan mengucapkan kalimat itu, tetapi juga memperhatikan konteks tuturan. Film pada dasarnya banyak memberikan refleksi dunia nyata. Inilah yang menjadikan film menarik untuk dikaji lebih mendalam, apalagi dialog antar pemainnya. Namun, terdapat hambatan dalam menentukan makna dialog dalam film tersebut (Setyanto, Bowo 2015). Sebuah film dikatakan dapat berkomunkasi dengan baik, jika berhasil menyampaikan pesan yang mengesankan kepada orang yang melihat atau penonton.

Menurut Indra (2013) dalam berinteraksi adanya upaya penyampaian gagasan melalui kerja sama antara penutur dengan mitra tutur. Untuk melaksanakan kegiatan tersebut, senantiasa terjadi kegiatan bertutur yang merupakan suatu tindakan yang mempunyai makna, fungsi, strategi, dan konteks pemakaian. Setyanto (2015:2) menyatakan suatu tuturan pasti mempunyai maksud serta faktor yang melatarbelakangi penutur dalam menyampaikan tuturannya kepada mitra tutur. Ketika terjadi tindak tutur diharapkan adanya reaksi yang timbul dari ujaran yang diucapkan. Tuturan yang diucapkan hendaknya memperlihatkan situasi dan konteks tuturan. Menurut Saputri 
(2014) tindak tutur adalah sesuatu yang dikatakan sambil bertindak dan adanya reaksi yang diharapkan dari kata-kata tersebut. Hermita (2014) menyatakan bahwa tindak tutur dan peristiwa tutur merupakan adanya dua gejala yang terdapat pada suatu proses komunikasi atau tindak yang dilakukan dalam menyampaikan atau menyebutkan suatu maksud oleh penuturnya (Danty, 2017).

Dwika (2017) menyatakan bahwa tindak tutur dalam ujaran suatu kalimat merupakan penentu makna kalimat itu. Namun, makna suatu kalimat tidak ditentukan oleh satu-satunya tindak tutur seperti yang berlaku dalam kalimat yang sedang diujarkan itu, tetapi selalu dalam prinsip adanya kemungkinan untuk menyatakan secara tepat apa yang dimaksudkan oleh penuturnya. Menurut Utami (dalam Purba, 2011) jika tuturan dikaitkan antara penutur dengan petutur, tuturan tersebut dapat membentuk suatu tindak tutur dan peristiwa tutur yang merupakan isi pembicaraan (Utami, 2014: 2). Ketika seseorang berkomunikasi, maka pada saat itu tindakan tuturan terjadi (Intan dan Etika, 2020:251). Komunikasi lisan penutur harus memperhatikan konteks yang menyertai ujaran tersebut. Menurut Austin (dalam Ekawati, 2017: 2-3) peristiwa komunikasi membedakan tiga jenis tindakan yaitu tindak tutur lokusi dimana tindak tutur ini mengucapkan sesuatu dengan kata dan kalimat sesuai dengan makna di dalam kamus dan menurut kaidah sintaksisnya. Tindak tutur ilokusi yaitu tindak tutur yang mengandung maksud, berkaitan dengan siapa bertutur kepada siapa, kapan, dan dimana tindak tutur itu dilakukan. Tindak tutur perlokusi yaitu tindak tutur yang pengajarannya dimaksudkan untuk mempengaruhi mitra tutur.

Elmita (2013: 139) menyatakan bahasa merupakan objek kajian linguistik atau ilmu bahasa. Cabang ilmu yang mengakaji bahasa berdasarkan konteks adalah pragmatik. Sejalan dengan itu, Leech (dalam Ellini, 2014) menyatakan konteks sangat penting dalam kajian pragmatik. Menurut Leech (dalam Agathy, 2013: 372) bahwa pragmatik mempelajari maksud ujaran (yaitu untuk apa ujaran itu dilakukan), menanyakan apa yang seseorang maksudkan dengan suatu tindak tutur, dan mengaitkan makna dengan siapa berbicara kepada siapa, di mana, bilamana, dan bagaimana. Leech (dalam Nurullita, 2018) menyatakan bahwa konteks yang terpenting dalam pragmatik adalah latar belakang pemahaman yang dimiliki oleh penutur dan mitra tutur dalam membuat interpretasi mengenai apa yang dimaksud oleh penutur ketika membuat aturan. Menurut Erliana (2013: 127) bahasa dalam penggunaannya dibedakan menjadi dua macam yaitu bahasa lisan dan bahasa tulisan. Bahasa lisan sangat terikat oleh kondisi, situasi, ruang, waktu, dan mimik pembicara.

\section{B. Fokus Masalah}

1. Penelitian ini lebih memfokuskan mengenai bentuk tindak tutur apa saja yang digunakan dalam film pendek Setengah Hari Kurang Sedikit tersebut.

2. Peneliti juga mendeskripsikan jenis bentuk tindak tutur apa saja yang digunakan pada dialog dalam film pendek Setengah Hari Kurang Sedikit tersebut. 


\section{Tujuan Penelitian}

Tujuan penelitian ini yaitu mendeskripsikan bentuk-bentuk tindak tutur dalam film pendek Setengah Hari Kurang Sedikit.

\section{Manfaat Penelitian}

1. Peneliti mengharapkan agar hasil dari penelitian ini menjadi salah satu alternatif bahan pembelajaran teks dalam bidang pragmatik yang dikaji.

2. Sesuai dengan hasil penelitian ini, peneliti berharap agar peneliti lain termotivasi untuk mengkaji lebih dalam lagi dan lebih baik lagi terkait dengan hasil penemuan dari penelitian ini sebelumnya.

\section{E. Batasan Istilah}

1. Komunikasi

Komunikasi memiliki arti sebagai ungkapan yang akan disampaikan oleh si penutur terhadap lawan tuturnya. Namun, terkadang maksud yang ingin disampaikan oleh si penutur tidak dapat dipahami oleh si pendengar.

2. Pragmatik

Pragmatik mempelajari maksud ujaran (yaitu untuk apa ujaran itu dilakukan), menanyakan apa yang seseorang maksudkan dengan suatu tindak tutur, dan mengaitkan makna dengan siapa berbicara kepada siapa, di mana, bilamana, dan bagaimana.

3. Tindak tutur

Tindak tutur dan peristiwa tutur merupakan adanya dua gejala yang terdapat pada suatu proses komunikasi atau tindak yang dilakukan dalam menyampaikan atau menyebutkan suatu maksud oleh penuturnya

4. Film

Dalam memahami sebuah film, setiap penonton film memiliki persepsi berbeda-beda dalam memahami makna didalam film tersebut disesuaikan dengan konteks yang ada.

\section{F. Sistematika Penyajian}

Penulisan penelitian ini meliputi lima bab. Bab I berisi pendahuluan. Pendahuluan terdiri dari latar belakang masalah, fokus masalah, tujuan penelitian, manfaat penelitian, batasan istilah, dan sistematika penyajian. Bab II menguraikan landasan teori. Landasan teori meliputi penelitian yang relevan, lingkup dan fenomena pragmatik, dan kerangka berpikir. Bab III memaparkan mengenai metodologi penelitian. Metodologi penelitian berisi jenis penelitian, subjek dan objek penelitian, sumber data penelitian, teknik pengumpulan data, instrumen penelitian, dan teknik analisis data. Bab IV memaparkan hasil penelitian dan pembahasan. Hasil penelitian berisi paparan dari data yang didapat dari analisis data. Bab $\mathrm{V}$ berisi penutup, dalam penutup berisi kesimpulan dan saran mengenai penelitian yang dibahas dalam skripsi tersebutt 


\section{BAB II}

\section{LANDASAN TEORI}

Hal yang akan diuraikan pada bab ini yaitu (1) penelitian yang relevan, (2) lingkup dan fenomena pragmatik, dan (3) kerangka berpikir. Pada pembahasan mengenai lingkup dan fenomena pragmatik, akan dibahas mengenai pragmatik, fenomena pragmatik, peristiwa tutur, tindak tutur, tindak tutur lokusi, tindak tutur ilokusi, dan tindak tutur perlokusi.

\section{A. Penelitian yang Relevan}

Suatu penelitian pada dasarnya berpedoman pada penelitian yang telah dilakukan sebelumnya oleh peneliti lain. Hal ini dapat dijadikan titik tolak pada penelitian sebelumnya. Mengetahui atau meninjau terhadap penelitian sebelumnya sangatlah penting untuk dilakukan. Selain itu, peninjauan terhadap penelitian sebelumnya juga berfungsi sebagai media untuk membandingkan seberapa besar penelitian yang telah dilakukan oleh peneliti sebelumnya. Ketika melakukan penelitian ini, peneliti menemukan beberapa penelitian dengan topik yang relevan dengan judul penelitian yang akan diteliti, diantaranya penelitian yang berjudul "Bentuk Tindak Tutur Ilokusi dalam Program Sentilan Sentilun" karya Andreas Dwi Yulianto dan "Tidak Tutur Lokusi dan Perlokusi dalam Dialog Film 5 CM Karya Mantovani” oleh Sella Oktaviani.

Penelitian pertama yaitu dari Andreas Dwi Yunianto mahasiswa Program Studi Bahasa Sastra Indonesia, Jurusan Pendidikan Bahasa dan Seni, Fakultas Keguruan dan Ilmu Pendidikan, Universitas Sanata Dharma. Skripsinya yang berjudul "Bentuk Tindak Tutur Ilokusi dalam Program Sentilan Sentilun". Hasil

penelitian ini menunjukkan bahwa peneliti menemukan empat bentuk tindak tutur ilokusi yang sering digunakan dalam tuturan pada program Sentilan Sentilun. Keempat wujud tindak tutur ilokusi itu adalah tindak tutur ilokusi direktif, tindak tutur ilokusi ekspresif, tindak tutur ilokusi deklaratif, dan tindak tutur ilokusi representatif. Pada penggunaan tindak tutur ilokusi ilokusi direktif, bentuk tuturan yang sering muncul mencakup 1) saran, 2) perintah, 3) permintaan, dan 4) ajakan. Pada penggunaan tindak tutur ilokusi ekspresif, bentuk tuturan yang sering muncul mencakup ungkapan 1) kekecewaan, 2) ketidaksenangan, dan 3) ketidaksukaan. Pada penggunaan tindak tutur ilokusi representtaif, bentuk tuturan yang sering muncul mencangkup 1) mempertahankan, 2) mengatakan, dan 3) mendeskripsikan. Pada penggunaan tindak tutur ilokusi komisif, bentuk tuturan yang sering muncul mencakup menawarkan. Pada penggunaan tindak tutur ilokusi deklaratif, bentuk tuturan yang sering muncul mencakup menyatakan.

Penelitian kedua yang relevan dengan penelitian ini yaitu penelitian dari Sella Oktaviani mahasiswa Program Studi Pendidikan Bahasa dan Sastra Indonesia, 
Fakultas Keguruan dan Ilmu Pendidikan, Universitas Muhammadiyah Surakarta. Skripsinya yang berjudul "Tindak Tutur Lokusi dan Perlokusi dalam Dialog Film 5 CM Karya Rizal Mantovani”. Berkaitan dengan tindak tutur lokusi dan perlokusi dalam dialog film 5 CM karya Rizal Mantovani terdapat beberapa tindak tutur yang termasuk ke dalam jenis tindak tutur lokusi dan tindak tutur perlokusi. Dalam menganalisis tuturan lokusi dalam dialog film 5 CM karya Rizal Mantovani tidak mengaitkan tindak tutur dengan konteks tuturan, karena tindak tutur lokusi merupakan tindak tutur yang hanya dalam arti "berkata". Penelitian skripsi ini ditemukan tiga puluh tindak tutur lokusi. Tindak tutur ini untuk menyampaikan informasi dari penutur kepada lawan tutur.

\section{Pragmatik}

Tarigan (1986: 34) menyatakan pragmatik yaitu telaah umum mengenai bagaimana caranya konteks mempengaruhi cara menafsirkan kalimat. Telaah mengenai bagaimana cara melakukan sesuatu dengan memanfaatkan kalimatkalimat adalah telaah mengenai tindak ujar yang harus menyadari benar-benar betapa pentingnya konteks ucapan atau ungkapan. Parera (2001: 126) menjelaskan pragmatik adalah kajian pemakaian bahasa dalam komunikasi, hubungan antara kalimat, konteks, situasi, dan waktu diujarkannya dalam kaliamat tersebut.

Pengertian dan pemahaman bahasa mengacu pada fakta bahwa untuk mengerti suatu ujaran bahasa diperlukan juga pengetahuan di luar makna kata dan hubungan tata bahasanya, yakni hubungan dengan konteks pemakainya. Hal ini berarti pragmatik berusaha menggambarkan sebuah ujaran yang disampaikan oleh penutur atau pembicara sebuah ujaran yang disampaikan oleh penutur atau pembicara dengan mengetahui makna tersebut.

Berdasarkan penjelasan tersebut, dapat disimpulkan bahwa pragmatik adalah ilmu yang mempelajari bahasa dalam pemakainya serta makna yang dihasilkan oleh kalimat yang dapat diketahui dengan melihat konteks yang ada saat tuturan tersebut berlangsung, maka kita dapat mengetahui makna yang diinginkan oleh pembicara dengan memperhatikan konteks yang melingkupi peristiwa tutur tersebut.

\section{Fenomena Pragmatik}

Pada dasarnya pragmatik mengkaji enam fenomena, yaitu praanggapan, tindak tutur, implikatur, deiksis, kesantunan, dan ketidaksatunan. Namun, pada penelitian ini hanya akan membahas fenomena pragmatik yaitu tindak tutur, baik itu tindak tutur lokusi, tindak tutur ilokusi, dan tindak tutur perlokusi.

\section{Peristiwa Tutur}

Ketika berkomunikasi atau berinteraksi, penutur maupun lawan tutur tentunya memerlukan sarana. Peristiwa tutur adalah proses berlangsungnya 
interaksi antara dua pihak yaitu penutur dan lawan tutur dalam waktu yang sama. Jadi, interaksi yang berlangsung antara tokoh-tokoh dalam film ini pada waktu tertentu dengan menngunakan bahasa sebagai alat komunikasinya adalah sebuah peristiwa tutur.

Dalam peristiwa sebuah percakapan baru dapat disebut sebagai sebuah peristiwa tutur kalau memenuhi syarat. Menurut Dell Hymes (1972) bahwa suatu peristiwa tutur harus memenuhi delapan komponen yaitu sebagai berikut:

a. Setting and scene

Setting berkenaan dengan waktu dan tempat tutur itu berlangsung, sedangkan scene lebih mengeacu pada situasi tempat, dan situasi psikologi pembicaraan. Jika waktu, tempat, dan situasi tuturan berbeda dapat menyebabkan penggunaan variasi bahasa yang berbeda-beda pula.

b. Participant

Participant adalah pihak-pihak yang terlibat dalam terjadinya peristiwa tutur, bisa pembicara atau pendengar, penyapa dan pesapa, atau pengirim dan penerima.

c. Ends

Ends merupakan maksud dan tujuan pertuturan tersebut. Apa maksud dan tujuan dari tuturan yang terjadi pada peristiwa tutur tersebut.

d. Act sequence

Act sequence mengacu kepada bentuk ujaran yang digunakan. Bentuk ujaran ini berkenaan dengan kata-kata yang digunakan, bagaimana penggunaannya, dan hubungan antara apa yang dikatakan dengan topik pembicaraan.

e. Key

Key lebih mengacu pada nada, cara, dan semangat dimana suatu pesan disampaikan dengan serius, singkat, sombong, dan lain sebagainya. Hal ini dapat ditujukan dengan gerak tubuh isyarat.

f. Instrumentalis

Instrumentalis merupakan jalur bahasa yang digunakan, seperti jalur lisan, tulisan. Selain itu, ia juga mengacu pada kode ujaran yang digunakan, seperti bahasa dialek, fragan, atau register.

g. Norm of intercation and interpretation

Hal ini lebih mengacu pada norma atau aturan dalam berinterkasi antara penutur dengan lawan tuturnya.

h. Genre

Genre mengacu pada jenis bentuk penyampaian, seperti narasi, puisi, pepatah, doa, dan lain sebagainya.

\section{Tindak Tutur}

Yule (dalam Laaksonen, 2019) menyatakan bahwa tindak tutur memungkinkan kita untuk mengetahui bagaimana pembicara bermaksud 
menafsirkan pesan, karena kita biasanya dapat mengenali jenis tindakan atau tindak tutur yang dilakukan pembicara dengan ujaran. Tindak tutur merupakan gejala individu, bersifat psikologis, dan ditentukan oeh kemampuan bahasa penutur dalam menghadapi situasi tertentu. Tindak tutur adalah kegiatan seseorang menggunakan bahasa kepada mitra tutur dalam rangka mengomunikasikan sesuatu. Apa makna yang dikomunikasikan tidak hanya dapat dipahami berdasarkan penggunaan bahasa dalam bertutur tersebut tetapi juga ditentukan oleh aspek-aspek komunikasi secara komprehensif, termasuk aspekaspek situasional komunikasi. Tiap tuturan (dalam wacana atau percakapan) yang disampaikan oleh penutur atau penulis kepada mitra tutur atau pembaca mempunyai makna atau maksud dengan tujuan tertentu. Makna atau maksud dan tujuan tuturan itu (dapat dikatakan) menyatakan tindakan. Maksud dan tujuan yang menyatakan tindakan yang melekat pada tuturan itu disebut dengan tindak tutur.

\section{Tindak Tutur Lokusi}

Tindak tutur lokusi merupakan tindak tutur yang berisi pernyataan. Tindak tutur ini biasanya bertujuan untuk menyampaikan informasi, menanya, atau mengklarifikasi sesuatu di dalam tuturannya (Rohmadi, 2014: 55). Sejalan dengan itu, menurut Dina (2012: 4) tindak tutur lokusi adalah tindak tutur yang semata-mata hanya bermaksud untuk menyatakan sesuatu sesuai dengan tuturan yang diucapkan tanpa adanya maksud lain di dalamnya. Tindak tutur semacam ini biasanya tidak mempermasalahkan maksud dan fungsi tuturan yang disampaikan oleh penutur. Selain itu, tindak tutur lokusi adalah tindak tutur untuk menyatakan sesuatu bagaimana adanya atau the act of saying something (tindakan untuk mengatakan sesuatu).

\section{Tindak Tutur Ilokusi}

Menurut Rohmadi (2014: 56) tindak tutur ilokusi adalah tindak tutur yang menyatakan dan memiliki maksud di balik tuturannya. Hal ini dimaksudkan bahwa di balik tuturan yang diucapkan oleh seseorang penutur memiliki maksud terselubung di balik tuturannya. Oleh karena itu, tindak tutur ini digunakan dengan maksud, seperti mengklarifikasi, menyindir, atau pun menguatkan suatu praduga seorang penutur kepada lawan tutur. Tindak tutur ilokusi adalah tindak tutur yang tidak hanya berfungsi untuk mengatakan sesuatu dengan yang dituturkan oleh penutur saja, akan tetapi dapat juga dipergunakan untuk melakukan sesuatu. Tindak tutur seperti ini biasanya memiliki maksud dan fungsi tertentu (Dina, 2012: 5). Tindak tutur ilokusi selain menyatakan sesuatu juga menyatakan tindakan melakukan sesuatu. Oleh karena itu, tindak tutur ilokusi ini disebut the act doing something (tindakan melakukan sesuatu)

\section{Tindak Tutur Perlokusi}


Menurut Rohmadi (2014: 57) tindak tutur perlokusi merupakan tindak tutur yang menyatakan sesuatu kepada awan tutur dan memiliki dampak langsung kepada lawan tutur. Tindak tutur perlokusi adalah tindak tutur yang diutarakan oleh seseorang dan seringkali mempunyai daya pengaruh atau efek bagi yang mendengarkannya. Efek atau daya pengaruh ini dapat secara sengaja maupun tidak sengaja dikreasikan oleh penuturnya (Dina, 2012: 6). Selain itu, tindak tutur perlokusi disebut juga sebagai the act of affective someone (tindak yang memberi efek pada orang lain).

\section{B. Kerangka Berpikir}

Penelitian ini akan berfokus pada tuturan yang terdapat dalam film pendek Setengah Hari Kurang Sedikit tersebut. Pengamatan hasil tuturan tokoh difokuskan pada jenis tindak tutur lokusi, tindak tutur ilokusi, dan tindak tutur perlokusi. Berdasarkan hasil tuturan tokoh dalam film pendek tersebut, kemudian dilakukan analisis untuk menentukan bentuk tindak tutur yang muncul dalam tuturan film pendek Setengah Hari Kurang Sedikit tersebut. 


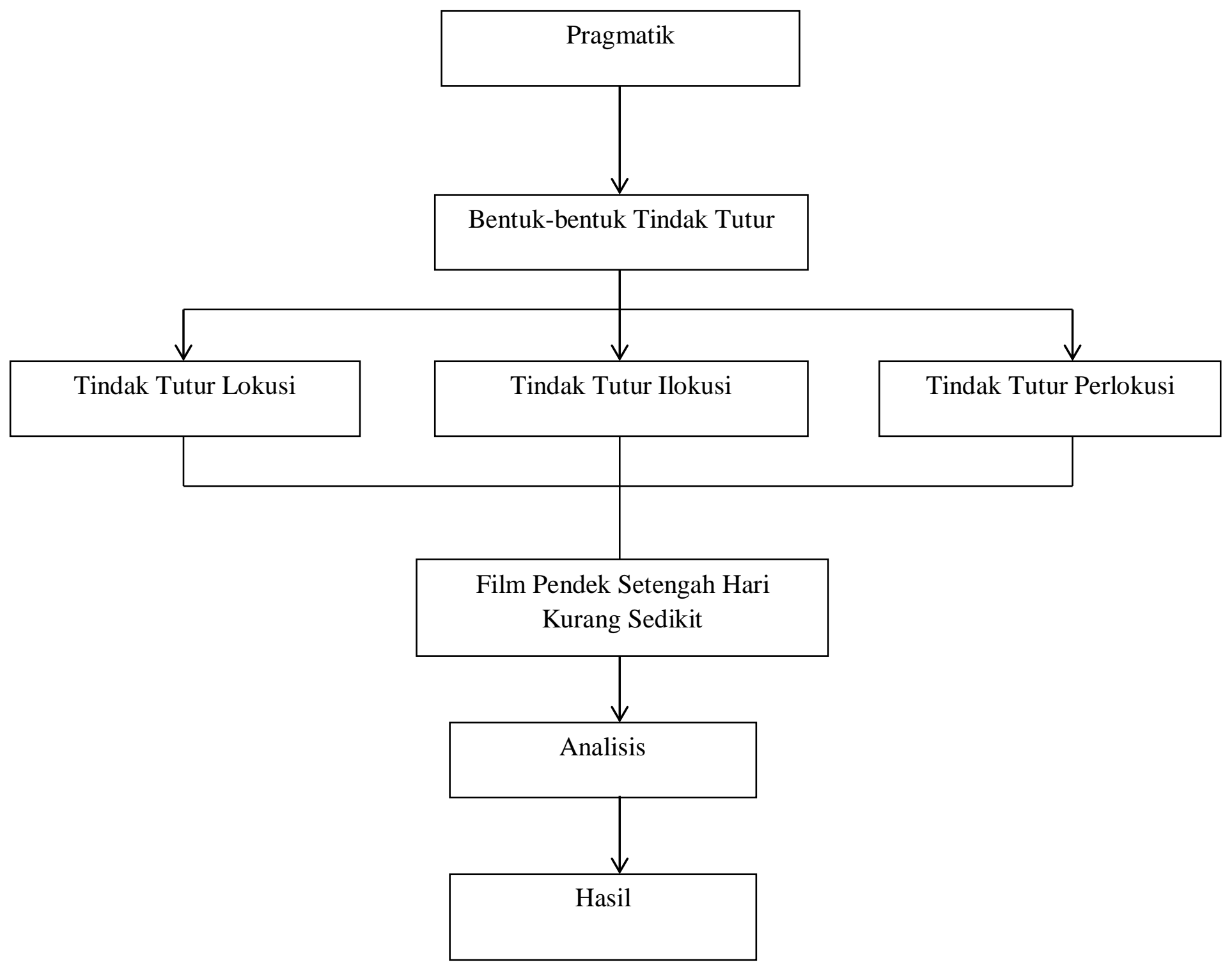




\section{BAB III \\ METODOLOGI PENELITIAN}

\section{A. Jenis Penelitian}

Jenis Penelitian yang berjudul "Bentuk Tindak Tutur dalam Film Setengah Hari Kurang Sedikit" ini merupakan penelitian deskriptif kualitatif. Pada penelitian ini dideskripsikan bentuk tutur yang digunakan dalam film pendek Setengah Kurang Sedikit tersebut. Penelitian ini lebih berfokus pada penemuan fakta-fakta keadaan sebenarnya. Metode deskriptif merupakan metode penelitian yang menganalisis suatu dokumen dan menjabarkan kembali, sehingga jenis penelitian deskriptif ini dilakukan terhadap informasi yang didokumentasikan melalui rekaman, gambar, suara, dan tulisan.

Selama proses penelitian yang dilakukan, peneliti menghindari melakukan manipulasi terhadap objek yang diteliti. Semua bentuk tindak tutur dalam film tersebut diteliti dengan sebenarnya. Berdasarkan permasalahan, tujuan dari penelitian ini untuk memperoleh deskriptif dan penjelasan tentang bentuk tindak tutur yang digunakan dalam film pendek Setengah Hari Kurang Sedikit tersebut.

\section{B. Subjek dan Objek Penelitian}

Menurut Arikunto (2003) subjek penelitian merupakan benda, hal, atau orang, tempat data penelitian melekat, dan dipermasalahkan. Subjek penelitian ini yaitu tayangan atau film Setengah Hari Kurang Sedikit tersebut. Objek penelitian ini yaitu tindak tutur yang terdapat dalam tayangan video tersebut.

\section{Sumber Data Penelitian}

1. Data

Data dalam penelitian ini adalah bentuk tindak tutur yang digunakan oleh pemain dalam berkomunikasi antar pemain, baik itu tindak tutur lokusi, tindak tutur ilokusi, dan tindak tutur perlokusi.

2. Sumber Data

Sumber data dalam penelitian ini adalah pemain dalam film Setengah Hari Kurang Sedikit tersebut.

\section{Teknik Pengumpulan Data}

Teknik pengumpulan data yang digunakan oleh peneliti dalam penelitian ini yaitu teknik simak dan catat. Berikut langkah-langkah yang dilakukan dalam teknik pengumpulan data. 
1. Peneliti menyimak film Setengah Hari Kurang Sedikit tersebut. menyimak, hal ini dilakukan peneliti untuk mememahmi tuturan mana saja yang termasuk dalam data yang akan dianalisis

2. Kemudian, peneliti melakukan transkrip tuturan dengan metode catat. Metode catat adalah teknik lannjutan yang dilakukan ketika menerapkan metode simak. Metode mencatat yang dilakukan bertujuan untuk melakukan pencatatan pada setiap tuturan yang terdapat dalam film Setngah Hari Kurang Sedikit tersebut.

\section{E. Instrumen Penelitian}

Instrumen penelitian ini adalah peneliti sendiri. Yang dimaksud dengan penelitian sendiri adalah peneliti sekaligus merupakan perencana, pelaksana pengumpul data, analisis, penafsir data, dan pada akhirnya menjadi pelapor hasil penelitiannya. Peneliti kualitatif yang menjadi instrumen atau alat penelitia adalah peneliti sendiri yang berbekal tentang pemahaman kajian teori pragmatik yaitu tindak tutur.

\section{F. Teknik Analisis Data}

Teknik analisis data yang digunakan oleh peneliti dalam penelitian ini, sehingga peneliti menemukan data tuturan pada penanyangan film Setengah Hari Kurang Sedikit antara lain:

1. Identifikasi data, hal ini dilakukan dengan tujuan untuk menemukan tuturan yang terdapat dalam film pendek Setengah Hari Kurang Sedikit tersebut.

2. Klasifikasi data, pada tahap ini peneliti mengelompokkan tuturan ke dalam tiga kelompok jenis tindak tutur, yaitu tindak tutur lokusi, tindak tutur ilokusi, dan tindak tutur perlokusi.

3. Deskripsi, hal ini dilakukan dengan tujuan untuk mendeskrispsikan data yang telah dikelompokkan sebelumnya. 


\section{Daftar Pustaka}

Agathy, Amazeli Renzy. 2013. Tindak Tutur dalam Pojok Mang Usil di Surat Kabar Harian Kompas. Jurnal Pendidikan Bahasa dan Sastra Indonesia, 2(2), 371-380.

Danty. 2017. Tindak Tutur Direktif dan Strategi Bertutur dalam Bahasa Minangkabau oleh

Remaja Antarkawan Sebaya Pada Komunikasi Resmi di Kota Padang. Jurnal Pendidikan Bahasa dan Sastra Indonesia, 5(1), 1-11.

Dell, Hymes. 1972. Sosiolinguistik: Perkenalan Awal. Jakarta: PT Rineka Cipta.

Dina, Puspita Sari Fenda. 2012. Tindak Tutur dan Fungsi Tuturan Ekspresif dalam Acara Galau Nite di Metro TV: Suatu Kajian Pragmatik. Jurnal Skriptorium, 1(1), 1-14.

Dwika, Ramanda Arnola. 2017. Tindak Tutur Ilokusi Pada Pidato Kenegaraan Presiden Jokowi Tanggal 14 Agustus 2015. Jurnal Pendidikan Bahasa dan Sastra Indonesia, 5(1), 1-12.

Dwi, Yunianto, Andreas. 2017. Bentuk Tindak Tutur Ilokusi dalam Program Sentilan Sentilun. Skripsi diterbitkan. Yogyakarta: Universitas Sanata Dharma.

Ekawati, Mursia. 2017. Kesantunan Semu Pada Tindak Tutur Ekspresif Marah dalam Bahasa Indonesia. Jurnal Bahasa dan Sastra, 1(1), 1-22.

Ellini, Mefi. 2014. Tindak Tutur Ilokusi Ustaz Yusuf Mansur dalam Acara Wisata Hati di Stasiun Televisi ANTV. Jurnal Pendidikan Bahasa dan Sastra Indonesia, 2(2), 1-14.

Elmita Winda. 2013. Tindak Tutur Direktif dalam Proses Mengajar di TK Nusa Indah Banuaran Padang. Jurnal Pendidikan Bahasa dan Sastra Indonesia, 1(2), 139-147.

Erlian, Wahyu. 2013. Tindak Tutur Deklarasi Bahasa Minangkabau Pedagang Kaki Lima di Pasar Raya Padang. Jurnal Pendidikan Bahasa dan Sastra Indonesia, 1(2), 127-138

Frandika, Edo dan Idawati. 2020. Tindak Tutur Ilokusi dalam Film Tilik (2018). Jurnal Pendidikan Bahasa Indonesia, 3(2), 61-69.

Hermita, Leli. 2014. Tindak Tutur Direktif Pedagang Pakaian dalam Bahasa Mandailing di Pasar Ujung Gading Kabupaten Pasaman Barat. Jurnal Pendidikan Bahasa dan Sastra, 2(2), 1-12.

Indra, Lesmana Windi. 2013. Tindak Tutur Juru Parkir di Pasar Balai Tangah Kecamatan Lintau Buo Utara Kabupaten Tanah Datar. Jurnal Pendidikan Bahasa dan Sastra Indonesia, 2(1), 131-146.

Intan, Saputri Ulin. 2020. Analisis Bentuk Tindak Tutur Direktif dalam Dialog Film Rembulan Tenggelam di Wajahmu Karya Tere Liye. Jurnal Kajian Bahasa, Sastra, dan Pengajaran, 3(2), 249-260.

Ismiati. 2020. Tindak Tutur Direktif dalam Film Keluarga Cemara Sutradara Yandy Laurens 
dan Implikasi terhadap Pendidikan. Jurnal Pendidikan Rokania, 5(2), 258-270.

Maulidah, Madinah. 2020. Analisis Tindak Tutur Ilokusi dalam Film Kuсumbu Tubuh Indahku Karya Garin Nugroho. Jurnal Bahasa dan Sastra Indonesia.1-10.

Miranda, Ayuri Septie. 2018. Tindak Tutur Ilokusi Peserta Diskusi dalam Acara ILC (Indonesia Lawyers Club) di Stasiun Televisi TV One Edisi Kasus Dugaan Korupsi Setya Novanto. Jurnal Pendidikan Bahasa dan Sastra Indonesia, 6(2), 1-15.

Nurullita, Rahma Anis. 2018. Analisis Tindak Tutur Ilokusi dalam Dialog Film Animasi Meraih Mimpi. Jurnal, 2(2), 13-24.

Oktaviani, Sella. 2015. Tindak Tutur Lokusi dan Perlokusi dalam Dialog Film 5 CM Karya Rizal Mantovani. Skripsi diterbitkan. Surakarta: Universitas Muhammadiyah Surakarta.

Purba, Andiopenta. 2011. Tindak Tutur dan Peristiwa Tutur. 1(1), 77-91.

Purwo, Bambang Kaswanti. 1984. Deiksis dalam Bahasa Indonesia. Jakarta: Balai Pustaka.

Ratna, Widayanti Sukasih dan Kustinah. 2019. Analisis Pragmatik Pada Fungsi Tindak Tutur dalam Film Karya Walt Disney. Jurnal Linguistik, 4(2), 180-185.

Rohmadi, Muhammad. 2014. Kajian Pragmatik Percakapan Guru dan Siswa dalam Pembelajaran Bahasa Indonesia. Jurnal Paedagogia, 17(1), 53-61.

Rosnilawati. 2013. Tindak Tutur dan Strategi Bertutur dalam Pasambahan Maantaan Marapulai Pesta Perkawinan di Alahan Panjang Kabupaten Solok. Jurnal Pendidikan Bahasa dan Sastra Indonesia, 1(2), 461-468.

Saputri, Anil. 2014. Tindak Tutur Direktif dalam Iklan Perdana GSM. Jurnal Pendidikan Bahasa dan dan Sastra Indonesia, 2(2), 1-18.

Setyanto, Bowo. 2015. Tindak Tutur Iokusi dalam Film $5 \mathrm{~cm}$ Karya Rizal Mantovi (Sebuah Tinjauan Pragmatik). 1-11.

Tarigan, Hanry Guntur. 1986. Pengajaran Pragmatik. Bandung: Angkara 